\begin{tabular}{|l|l|r|}
\hline & Al Fitrah & Pengaruh Guru PAUD dalam \\
Journal Of Early Childhood Islamic Education & Menstimulasi Perkembangan \\
ISSN : 2599-2287 E-ISSN : 2622-335X & Kelompok B Usia 5-6 TAhun \\
& Wika Niati \\
\hline
\end{tabular}

\title{
PERAN GURU PAUD DALAM MENSTIMULASI PERKEMANGAN BAHASA ANAK PADA KELOMPOK B USIA 5-6 TAHUN DI TK DARMA WANITA KAB.SELUMA
}

\begin{abstract}
Abstrak
Berdasarkan observasi awal yang penulis lakukan, permasalahan yang ditemukan dilapangan adalah Bagaimana peran guru paud dalam menstimulasi perkembangan bahasa anak pada kelompok B di Tk Darma Wanita Kabupaten seluma. Jenis penelitian ini adalah Penelitian ini menggunakan pendekatan kualitatif, data dalam penelitian tidak diperoleh melalui prosedur statistik atau bentuk hitung lainnya. Penelitian kualitatif adalah penelitian yang bermaksud untuk memahami fenomena tentang apa yang dialami oleh subjek penelitian. Berdasarkan hasil penelitian peran guru paud dalam menstimulasi perkembangan bahasa anak pada kelompok B usia 5-6 tahun di Tk Darma Wanita Kabupaten seluma, guru sudah melakukan stimulasi kepada anak namun perlu ditingkatkan dengan mengunakan berbagai media yang lebih menarik serta mengunakan metode yang berbeda agar perkembangan bahasa pada anak semakin meningkat dan anak dapat mengunakan bahasa dalam berkomunikasi, peran guru paud dalam menstimulasi perkembangan bahasa anak pada kelompok B usia 5-6 tahun di Tk Darma Wanita Kabupaten Seluma dengan memberikan contoh mengajarkan stimulasi perkembangan bahasa anak didik agar perkembangan bahasa semakin meningkat dan aspek perkembangan bahasa dapat berkembangan sesuai dengan tahap usia anak.

Kata kunci: Peran Guru, Menstimulasi Perkembangan Bahasa Anak
\end{abstract}

\section{PENDAHULUAN}

PAUD merupakan singkatan dari pendidikan Anak Usia Dini. Pada UndangUndang Nomor 20 Tahun 2003 tentang sistem pendidikan nasional disebutkan bahwa pendidikan adalah usaha sadar dan terencana untuk mewujudkan suasana belajar dan proses pembelajaran agar peserta didik secara aktif dapat mengembangkan potensi dirinya untuk memiliki kekuatan spritual keagamaan, pengendalian diri, kepribadian, kecerdasan, akhlak mulia serta keterampilan yang diperlukan dirinya, masyarakat, bangsa dan 


\begin{tabular}{|l|l|r|}
\hline A1 Fitrah & Pengaruh Guru PAUD dalam \\
Journal Of Early Childhood Islamic Education & Menstimulasi Perkembangan \\
ISSN $:$ 2599-2287 E-ISSN : 2622-335X & Kelompok B Usia 5-6 TAhun \\
Vol.3 No.1Juli 2019 & Wika Niati \\
\hline
\end{tabular}

negara. Sedangkan usia dini adalah rentang usia 0 hingga 6 tahun. ${ }^{1}$

Pendidikan anak usia dini (PAUD) pada hakikat adalah pendidikan yang diselenggarakan dengan untuk memfasilitasi pertumbuhan dan perkembangan anak secara menyeluruh atau menekankan pada perkembangan seluruah aspek keperibadian anak, oleh karena itu, paud memberikan kesempatan bagi anak untuk mengembangkan keperibadian dan pontesi secara maksimal.

Anak usia dini merupakan kelompok usia yang berada dalam proses perkembangan unik karena proses perkembangannya (tumbuh dan kembang) terjadi bersamaan dengan golden age ( masa peka). Golden age merupakan waktu paling tepat untuk memberikan bekal yang kuat kepada anak. Di masa peka, kecepatan perumbuhan otak anak sangat tinggi hingga mencapai $50 \%$ dari keseluruan perkembangan otak anak selama hidupnya.

Artinya, golden age merupakan masa yang sangat tepat untuk menggali segala potensi kecerdasan anak sebanyakbanyaknya. Hasil kesempatan dunia, umur 0-8 tahun disebut dengan anak usia dini (AUD), sedangkan di indonesia usia dini disepakati antara 0-6 tahun. Anak-anak

\footnotetext{
${ }^{1}$ Anita Yus, Model Pendidikan Anak Usia
} Dini. Jakarta: Kecana Prenanda Media Group. 2011. pada masa usia dini memerlukan berbagai bentuki dan layanan dan bantuan orang dewasa, dari kebutuhan jasmani sampai rohani. Di mana bentuk layanan tersebut diarahkan untuk memfasilitasi pertumbuhan dan perkembangan manusia seutuhnya sehingga anak dapat tumbuh kembang secara optimal sesuai nilai, norma, serta harapan masyarakat.

Secara umum, tujuan pendidikan anak usia dini adalah memberikan stimulasi atau rangsangan bagi perkembangan pontensi anak agar menjadi manusia beriman dan bertakwa kepada Tuhan Yang Maha Esa, berakhlak mulia, sehat, berilmu, cakap, kritis, kreatif, inovatif, mandiri, percaya diri, dan menjadi warga negara yang demokratis dan bertanggung jawab.

Dalam Undang-undang Nomor 20 tahun 2003 tentang Sistem Pendidikan Nasional Pasal 1 ayat 14 dinyatakan bahwa pendidikan anak usia dini adalah suatu upaya pembinaan yang ditunjukan kepada anak sejak lahir sampai dengan usia enam tahun yang dilakukakan melalui pemberian rangsangan pendidikan untuk membatu pertumbuhan dan perkembangan jasmani dan rohani agar anak memiliki kesiapan dalam memasuki penddidkan 


\begin{tabular}{|l|l|r|}
\hline & Al Fitrah & Pengaruh Guru PAUD dalam \\
Journal Of Early Childhood Islamic Education & Menstimulasi Perkembangan \\
ISSN $:$ 2599-2287 E-ISSN : 2622-335X & Kelompok B Usia 5-6 TAhun \\
Vol.3 No.1Juli 2019 & Wika Niati \\
\hline
\end{tabular}

lebih lanjut. ${ }^{2}$ Dalam undang-undang sistem pendidikan disebutkan bahwa ruang lingkup lembaga-lembaga PAUD terbagi kedalam tiga jalur yaitu formal, non-formal, dan informal. Ketiganya merupakan jenjang pendidikan yang diselenggarakan sebelum pendidikan dasar. ${ }^{3}$

Lembaga pendidikan anak usia dini adalah suatu lembaga yang memberikan layanan pengasuhan pendidikan dan pengembangan bagi anak lahir sampai 6 tahun atau 6-8 tahun, baik yang diselenggarakan oleh instansi pemerintah dan non pemerintah. Oleh karena itu lembaga paud perlu menyediakan berbagai kegiatan yang dapat mengembangkan berbagai aspek perkembangan seperti kongnitif, bahasa, sosial, emosi, fisik, dan motorik.

Fungsi PAUD yang harus diperhatikan dapat dijelaskan sebagai berikut: 1. Untuk mengembangkan seluruh kemampuan yang dimiliki anak sesuai dengan tahapan perkembangan, 2. mengenalkan anak dengan dunia sekitar, 3. Mengembangkan sosialisasi anak, 4. mengenalkan peraturan dan menanamkan

\footnotetext{
2 Oemar Hamalik, Perencanaan Pengajaran Berdasarkan Pendekatan Sistem. Jakarta: Pt Bumi Aksara

Ibrahim Bafadal, Dasar-Dasar
} Manajemen Dan Supervisi Taman Kanak-Kanak. Jakarta: Pt Bumi Aksara. 2004 disiplin anak, 5. memberikan kesempatan pada anak untuk menikmati masa bermainya, 6. memberikan stimulasi kultural pada anak, 7. memberikan eksperesi stimulasi kultural.

Pengetahuan tentang prinsip perkembangan anak sangat penting untuk memperoleh gambaran keumuman perilaku anak pada tahap tetentu. pengetahuan ini juga bermanfaat untuk memberikan bimbingan dan rangsangan tertentu agar anak dapat mencapai kemampuan sepenuhnya, serta memungkinkan guru menyiapkan anak atas hal-hal yang diharapkan dari mereka pada usia tertentu. ${ }^{4}$

Urgensi pendidikan anak usia dini berdasarkan tinjauan didalam psikologi adalah untuk mengembangkan berbagai aspek aspek kecerdasaan yang merupakan pentensi bawaan. kecerdasan yang dimiliki oleh seseorang anak hanya akan berarti apabila dapat diterapkan dalam kehidupan sehari-hari, yang dikenal dengan istilah kecakapan hidup ( life skills). Maddaleno dan Infante (2001:5) berdasarkan hasil penelitian, mengidentifikasi tentang tiga kategori kunci tentang life skill yaitu keterampilan sosial dan interpersonal,

\footnotetext{
${ }^{4}$ Isjoni, Model Pembelajaran Anak Usia Dini. Bandung: Alfabeta. 2011
} 


\begin{tabular}{|l|l|r|}
\hline A1 Fitrah & Pengaruh Guru PAUD dalam \\
Journal Of Early Childhood Islamic Education & Menstimulasi Perkembangan \\
ISSN $:$ 2599-2287 E-ISSN : 2622-335X & Kelompok B Usia 5-6 TAhun \\
Vol.3 No.1Juli 2019 & Wika Niati \\
\hline
\end{tabular}

keterampilan kognitif dan keterampilan meniru emosi. ${ }^{5}$

Perkembangan anak usia dini perlu dirangsang sejak usia prasekolah, karena disitulah proses perkembangan anak sangat berkembang, terutama perkembangan bahasa anak. Bahasa meliputi setiap kata yang berhubungan dengan pemahaman, pertimbangan, pengelolahan informasi, pemecahan masalah, kesengajaan, dan keyakinan. Sebagian besar psikolog terutama cognitivist ( ahli psikologi kognitif) berkeyakinan bahwa proses perkembangan kognitif manusia mulai berlangsung sejak ia baru lahir. ${ }^{6}$

Guru memang menempati kedudukan yang terhormat di masyarakat. Guru dapat dihormati oleh masyarakat karena kewibawaannya, sehingga masayarakat tidak meragukan figur guru. Masyarakat percaya bahwa dengan adanya guru, maka dapat mendidik dan membentuk kepribadian anak didik mereka dengan baik agar mempunyai intelektualitas yang tinggi serta jiwa kepemimpinan yang bertanggungjawab. Jadi dalam pengertian yang sederhana, guru dapat diartikan sebagai orang yang memberikan ilmu pengetahuan kepada anak didik. Sedangkan

5 Nelva Rolina, Alat Permainan Edukatif Untuk Aud. Yogyakarta: Ombak 2012.

6 Asep Dadang, Mencerdaskan IQ , EQ DAN SQ. Bandung: Globalindo 2007 guru dalam pandangan masyarakat itu sendiri adalah orang yang melaksanakan pendidikan ditempat-tempat tertentu, tidak mesti di lembaga pendidikan yang formal saja tetapi juga dapat dilaksanakan dilembaga pendidikan non-formal seperti di masjid, di surau/mushola, di rumah dan sebagainya.

Guru mempunyai tanggung jawab mencerdaskan kehidupan anak didik. Pribadi susila yang cakap adalah diharapkan ada pada diri setiap anak. tidak ada seorang guru pun yang mengharapkan anak didiknya menjadi sampah masyarakat.untuk itulah guru dengan penuh dediksi dan layolitas berusaha membimbing dan membina anak didik agar dimasa datang menjadi orang yang berguna untuk nusa dan bangsa. Maka dari itu ayat / hadist tentang peran guru: Rasulullah Saw mengajarkan agar seorang guru mendidik dengan dengan cara yang lemah lembut, luwes dan tidak keras. Sebagaimana sabda Nabi Saw berikut:

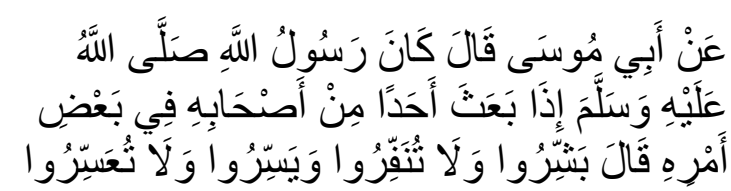

Dari Abu Musa berkata: Jika Rasulullah Saw mengutus seseorang dari para Sahabatnya dalam suatu perkara, beliau bersabda: "Berikanlah berita 


\begin{tabular}{|l|l|r|}
\hline & Al Fitrah & Pengaruh Guru PAUD dalam \\
Journal Of Early Childhood Islamic Education & Menstimulasi Perkembangan \\
ISSN $:$ 2599-2287 E-ISSN : 2622-335X & Kelompok B Usia 5-6 TAhun \\
Vol.3 No.1Juli 2019 & Wika Niati \\
\hline
\end{tabular}

gembira dan jangan membuat orang lari, permudahlah orang lain jangan engkau persulit”. (HR. Bukhari Muslim).

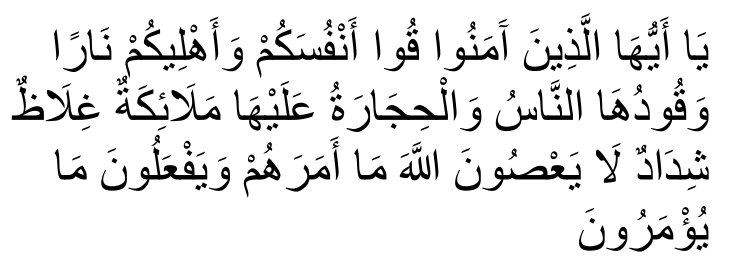

Artinya: Hai orang-orang yang beriman, peliharalah dirimu dan keluargamu dari api neraka yang bahan bakarnya adalah manusia dan batu; penjaganya malaikatmalaikat yang kasar, keras, dan tidak mendurhakai Allah terhadap apa yang diperintahkan-Nya kepada mereka dan selalu mengerjakan apa yang diperintahkan.

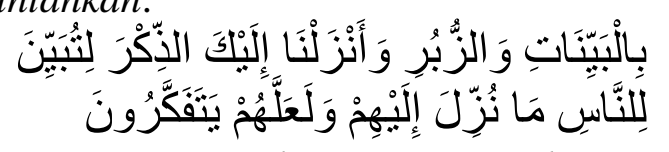

Artinya: Keterangan-keterangan (mukjizat) dan kitab-kitab. dan Kami turunkan kepadamu Al Quran, agar kamu menerangkan pada umat manusia apa yang telah diturunkan kepada mereka dan supaya mereka memikirkan.7

Pendidikan bahasa tidak mudah dengan keterampilan karena pendidikan itu mempunyai syarat-syarat yang berlainan dengan pendidikan keterampilan dan faktafakta. oleh karena itu sebagai guru kita harus berperan dalam pembelajaran terlalu dominan sehinga pembelajaran kurang bermakna, pengetahuan yang di dapat anak tidak bertahan lama. Maka dari itu sebagai guru kita harus mengambil strategi

7 https://ghofar1.blogspot.com/2016/11/ayat-hadistdalil-kewajiban-menghormati.html.23/11/2018 dengan pembelajaran media gambar agar anak dapat memprakktekan bahasa dengan baik dan benar. Bahasa merupakan sarana efektif untuk menjalin komunukasi sosial. tanpa bahasa, komunikasi tidak dapat dilakukan dengan baik dan interaksi sosial pun tidak akan pernah terjadi. karena tanpa bahasa, siapa pun tidak akan dapat mengesperesikan diri untuk menyampaikan kepada orang lain.

Selain itu ada berbagai persoalan yang dihadapi baik oleh guru atau pendidik dalam menyampaikan materi pembelajaran kepada anak didik di TK Darma Wanita, karena masih ada kosa kata anak yang belum bisa memahami setiap bacaan, sehingga diperlukan bimbingan dari guru dan orang tua dengan menggunakan berbagai media atau pun alat yang lain.

Berdasarkan hasil observasi awal di TK Darma Wanita Kabupaten Seluma pada tanggal 13 Mei 2018 menunjukan bahwa, masih ada beberapa stimulasi perkembangan bahasa anak yang belum berkembang pada saat melakukan kegiatan pembelajaran dengan menggunakan berbagai media.. Oleh karena itu ada beberapa hambatan yang menyebabkan sttimulasi anak perkembangan bahasa anak seperti kurangnya sarana dan prasarana, dan kurangnya tenaga pengajar, sehingga kurangnya optimal peningkatan peran guru 


\begin{tabular}{|l|l|r|}
\hline A1 Fitrah & Pengaruh Guru PAUD dalam \\
Journal Of Early Childhood Islamic Education & Menstimulasi Perkembangan \\
ISSN $:$ 2599-2287 E-ISSN : 2622-335X & Kelompok B Usia 5-6 TAhun \\
Vol.3 No.1Juli 2019 & Wika Niati \\
\hline
\end{tabular}

dalam menstimulasi perkembanagn bahasa anak dalam pembelajaran terutama yang berhubungan dengan perkembangan bahasa anak. Pembelajaran yang dilakukan berdasarkan observasi dan wawancara didapat dari guru paud melakukan kegiatan pembelajaran dengan menggunakan berbagai cara seperti bercerita, dengan mengajarkan anak untuk mendengarkan guru bercerita, lihat saat anak belajar di kelas selama 45 menit dengan jumlah anak 20 orang dan 4 guru. metode pengajaran yang dilakukan oleh guru untuk menstimulasi perkembangan bahasa pada anak mengungkapkan tujuan mengembangkan bahasa pada anak.

Berdasarkan permasalahan diatas penulis menyampaikan gagasan peran guru mestimulasi perkembangan bahasa anak didik di TK Darma Wanita. dengan satu metode membaca cepat dengan menunjukkan materi atau bahan kepada anak didik dengan cara yang tepat. Dengan guru mengajarkan atau mestimulasi perkembangan bahasa kepada anak didik sehingga perhatian anak berpusat pada pembelajaran yang guru lakukan. Selanjutnya setiap anak mendapat kesempatan dapat belajar bahasa dengan senang, nyaman, tenang tanpa tekanan.

Jadi dapat diketahui bahwa peran guru paud dalam menstimulasi perkembangan bahasa pada anak dikelompok B Usia 5-6 Tahun, peneliti harus langsung kelapangan dan melihat langsung pembelajaran apa yang sedang dipelajari. Oleh karena itu, penulis tertarik untuk mengkajinya Penelitian yang berjudul" Peran Guru Paud Dalam Menstimulasi Perkembangan Bahasa anak Pada Kelompok B Usia 5-6 Tahun Di Taman Kanak-Kanak Darma Wanita Kabupaten Seluma"

\section{A. Landasan Teori}

\section{Pengertian Peran Guru Paud}

Peranan adalah sesuatu yang jadi bagian atau memengang pemimpin yang teutama (dalam terjadinya sesuatu hal atau peristiwa). Peranan juga dikatakan pelaku atau lembaga yang punya arti penting bagi struktur sosial. Dalam hal ini, maka kata peranan lebih banyak mengacuh pada penyesuian diri pada suatu proses

Guru adalah semua orang yang berwenang dan bertanggung jawab terhadap pendidikan murid-murid, baik secara individual atau pun klasikal, baik di sekolah maupun diluar sekolah. Berdasarkan pendapat diatas dapat disimpulkan bahwa guru adalah sosok yang rela mencurahkan sebagian besar waktunya untuk mengajar dan mendidik siswa serta berwenang dan bertanggung jawab terhadap 


\begin{tabular}{|l|l|r|}
\hline Al Fitrah & Pengaruh Guru PAUD dalam \\
Journal Of Early Childhood Islamic Education & Menstimulasi Perkembangan \\
ISSN : 2599-2287 E-ISSN : 2622-335X & Kelompok B Usia 5-6 TAhun \\
Vol.3 No.1Juli 2019 & Wika Niati \\
\hline
\end{tabular}

pendidikan murid-murid, baik secara individual ataupun klasikal. ${ }^{8}$

Guru sebagai pendidik dan pengajar anak, guru diibaratkan seperti ibu kedua yang mengajarkan berbagai macam hal yang baru dan sebagai fasilitator anak supaya dapat belajar dan mengembangkan potensi dasar dan kemampuannya secara optimal, hanya saja ruang lingkupnya guru berbeda, guru mendidik dan mengajar di sekolah negeri ataupun swasta.

\section{Pengertian Perkembangan Bahasa}

Bahasa merupakan sarana yang efektif untuk menjalin komunikasi sosial tanpa bahasa, komunikasi tidak dapat dilakukan dengan baik dan interaksi sosial pun tidak akan pernah terjadi, karena tanpa bahasa, siapa pun tidak akan dapat mengespresikan diri unuk menyampaikan kepada orang lain. ${ }^{9}$ Bahasa adalah sarana berkomunikasi dengan orang lain. dalam pengertian ini tercakup semua cara untuk berkomunikasi di mana pikiran dan perasaan dinyatakan dalam bentuk lisan, tulisan, isyarat, atau gerak dengan menggunakan kata-kata, simbol, lambang, gambar atau lukisan. melalui bahasa,

8 Syaiful Bahri Djamarah, Guru Dan Anak Didik Dalam Interaksi Edukatif (Suatu Pendekatan Teoritis Psikologi). (Jakarta: PT Rineka Cipta. 2010), Hlm. 3

9 Djamarah Syaiful Bahri, Pisikologi Belajar, (Banjarmasin :IAIN Antasari Banjarmasin ,2000 ) hlm 46 manusia dapat mengenal dirinya, sesamanya, alam sekitar, ilmu pengetahuan, dan nilai-nilai moral atau agama. $^{10}$

Ditinjau dari perkembangannya, bahasa Anak Usia Dini merupakan masa pertumbuhan yang paling penting karena menentukan masa perkembangan selanjutnya dinyatakan bahwa perkembangan otaknya tersebut usia 0-8 tahun disebut sebagai usia (golde age). oleh karena itu, pendidikan AUD dirasa penting karena menentukan keberhasialn anak selanjutnya. untuk melihat keberhasilan tersebut, antara lain dapat dilihat dari perkembangan penguasan bahasanya yang dapat dilihat ketika anak berkomunikasi.

\section{B. Metode Penelitian}

Penelitian ini menggunakan pendekatan kualitatif, data dalam penelitian tidak diperoleh melalui prosedur statistik atau bentuk hitung lainnya. Penelitian kualitatif adalah penelitian yang bermaksud untuk memahami fenomena tentang apa yang dialami oleh subjek penelitian. ${ }^{11}$

10 Yusuf Syamsu, Perkembangan Peserta Didik, ( Jakarta : PT Rajarafindo Persada, 2011)

11 Ahmad Tanzeh, Metodologi Penelitian Praktis, (Yokyakarta: Teras, 2011), hlm 50 


\begin{tabular}{|l|l|r|}
\hline A1 Fitrah & Pengaruh Guru PAUD dalam \\
Journal Of Early Childhood Islamic Education & Menstimulasi Perkembangan \\
ISSN $:$ 2599-2287 E-ISSN : 2622-335X & Kelompok B Usia 5-6 TAhun \\
Vol.3 No.1Juli 2019 & Wika Niati \\
\hline
\end{tabular}

Penelitian kualitatif adalah salah satu prosedur penelitian yang menghasilkan data deskriptif berupa ucapan atau tulisan dan perilaku orang-orang yang diamati. Pendekatan kualitatif diharapkan mampu menghasilkan uraian yang mendalam tentang ucapan, tulisan, dan atau perilaku yang dapat diamati dari suatu individu, kelompok, masyarakat, dan atau organisasi tertentu dalam suatu keadaan konteks tertentu yang dikaji dari sudut pandang yang utuh, komprehensif, dan holistik. ${ }^{12}$

Penelitian yang menggunakan format kualitatif bertujuan untuk menggambarkan, meringkas berbagai kondisi, berbagai situasi, dan berbagai fenomena yang ada di masyarakat. ${ }^{13}$

Jenis penelitian ini bersifat kualitatif. Metode penelitian kualitatif adalah metode penelitian yang digunakan untuk meneliti pada kondisi obyek yang ilmiah, (sebagai lamanya eksperimen) dimana peneliti adalah instrumen kunci, teknik pengumpulan data dilakukan secara analisis data bersifat induktif/kuatitatif, dan hasil penelitian kualitatif lebuh menekankan makna dari pada generalisasi. ${ }^{\mathbf{1 4}}$

12 Wiratna Sujarweni, Metodologi Penelitian, (Yogyakarta:Pustaka Barupress, 2014) hlm. 19

13 Sugiono,Metode Penelitian Bisnis (Pendekatan Kualitatuf, Kuantitatif dan R\&D) Bandung : Alfabeta 2010

${ }^{14}$ Ahmad Tanzeh, Metodologi Penelitian Praktis, (Yokyakarta: Teras,2011), hlm 50

C. Pembahasan

1. Perkembangan Bahasa Pada Kelompok B Usia 5-6 Tahun Di Tk Darma Wanita Kab. Seluma

Berdasarkan hasil wawancara pada hasil penelitian,dapat peneliti simpulkan bahwa perkembangan bahasa pada kelompok B usia 5-6 secara umum sudah berkembang dengan baik, namun secara khusus masih ada beberapa anak yang perlu dibimbing dalam tahap perkembangan bahsa melalui berbicara, membaca, menyimak, dan menulis.

Dalam mengembangkan perkembangan bahasa atau kemampuan bahasa anak melalui tulisan maupun lisan, sebagai mana cara untuk mengesperesikan perasaan, pikiran, dan gagasan, maka sebaiknya anak dilatih untuk menarik minat anak untuk menyukai terkait dengan pengalaman hidupnya sendiri, atau pada umumnya dalam berbagai cara yang dilakukan untuk meningkatakan perkembangan bahsa anak.

Perkembangan bahasa anak usia dini merupakan adalah pengembangan bahasa. Bahasa memungkinkan anak untuk menerjemahkan pengalaman ke dalam simbol-simbol yang dapat digunakan untuk berkomunikasi dan 


\begin{tabular}{|l|l|r|}
\hline & A1 Fitrah & Pengaruh Guru PAUD dalam \\
Journal Of Early Childhood Islamic Education & Menstimulasi Perkembangan \\
ISSN $:$ 2599-2287 E-ISSN : 2622-335X & Kelompok B Usia 5-6 TAhun \\
& Wika Niati \\
\hline
\end{tabular}

berpikir. Belajar bahasa yang sangat krusial terjadi pada anak sebelum 6 tahun. Oleh karena itu, taman kanakkanak atau pendidikan prasakolah merupakan wahana yang sangat penting dalam mengembangkan bahasa anak. Anak memperoleh bahasa dari lingkunga keluarga dan dari lingkungan masyarakat. Perkembangan bahasa yang baik bagi mereka, dapat meningkatkan kosakata dengan cepat. Anak akan belajar bagaimana berpertisipasi dalam suatu percakapan dan menggunakan bahasanya untuk memecahkan masalah. Menggunakan bahasa untuk berkomunikasi dengan orang lain, anak akan mendapatkan benyak sekali kosakata, sekaligus dapat mengekspresikan dirinya melalui bahasa. $^{15}$

\section{Peran Guru Paud Dalam}

\section{Menstimulasi Perkembangan}

Bahasa Pada Kelompok B Usia 5-

6 Tahun Di Tk Darma Wanita

\section{Kab. Seluma.}

Berdasarkan hasil wawancara diatas, dapat peneliti pahami bahwa Peran guru paud dalam menstimulasi perkembangan bahasa

40. Gunarti Winda, Lilis Suryani, Azizah Muis.2008. Metode Pengembangan Perilaku dan Kemampuan Dasar Anak Usia Dini.(Jakarta: Universitas Terbuka, 2008), hlm.35 pada kelompok B usia 5-6 tahun di tk darma wanita, tujuannya untuk mengetahui peran guru dalam perkembangan bahasa anak, adapun pelaksanaan di luar kelas, secara kelompok setiap harinya supaya anak-anak tidak bosan dalam mengikuti pembelajaran

Dalam kegiatan belajar mengajar, guru memiliki peran yang cukup penting untuk membuat ilmuilmu yang diajarkan dapat diterima oleh siswa-siswa yang ada. Tak hanya berperan untuk mengajarkan ilmu-ilmu saja, banyak sekali peran guru dalam proses pembelajaran. Nah kali ini akan dibahas lebih lanjut mengenai peran guru di dalam proses kegaiatan belajar mengajar.

a) Guru Sebagai Pendidik

Guru merupakan pendidik, tokoh, panutan serta identifikasi bagi para murid yang di didiknya serta lingkungannya. Oleh sebab itu, tentunya menjadi seorang guru harus memiliki standar serta kualitas tertentu yang harus dipenuhi. Sebagai seorang guru, wajib untuk memiliki rasa tanggung jawab, mandiri, wibawa, serta kedisiplinan yang 


\begin{tabular}{|l|l||r||}
\hline Al Fitrah & Pengaruh Guru PAUD dalam \\
Journal Of Early Childhood Islamic Education & Menstimulasi Perkembangan \\
ISSN : 2599-2287 E-ISSN : 2622-335X & Kelompok B Usia 5-6 TAhun \\
Vol.3 No.1Juli 2019 & Wika Niati \\
\hline
\end{tabular}

dapat dijadikan contoh bagi

peserta didik.

\section{b) Guru Sebagai Pengajar}

Kegiatan belajar mengajar akan dipengaruhi oleh beragam faktor di dalamnya, mulai dari kematangan, motivasi, hubungan antara murid dan guru, tingkat kebebasan, kemampuan verbal, ketrampilan guru di dalam berkomunikasi, serta rasa aman. Jika faktor faktor tersebut dapat terpenuhi, maka kegiatan belajar mengajar dapat berlangsung dengan baik Guru harus dapat membuat sesuatu hal menjadi jelas bagi murid, bahkan terampil untuk memecahkan beragam masalah

c) Guru Sebagai Sumber Belajar

Peran guru sebagai sebuah sumber belajar akan sangat berkaitan dengan kemampuan guru untuk menguasai materi pelajaran yang ada. Sehingga saat siswa bertanya sesuatu hal, guru dapat dengan sigap dan tanggap menjawab pertanyaan murid dengan menggunakan bahasa yang lebih mudah dimengerti.

\section{d) Guru Sebagai Fasilitator}

Peran seorang guru sebagai fasilitator adalah dalam memberikan pelayanan agar murid dapat dengan mudah menerima dan memahami materi-materi pelajaran. Sehingga nantinya proses pembelajaran akan menjadi lebih efektif dan efisien.

\section{e) Guru Sebagai Pembimbing}

Guru dapat dikatakan sebagai pembimbing perjalanan, yang mana berdasar pengetahuan serta pengalamannya dan memiliki rasa tanggung jawab dalam kelancaran perjalanan tersebut. Perjalanan ini tidak hanya sola fisik namun juga perjalanan mental, kreatifitas, moral, emosional dan spritual yang lebih kompleks dan dalam.

\section{Kesimpulan}

Berdasarkan hasil penelitian dan pembahasan dalam Bab IV maka dapat dibuat kesimpulan yang merupakan jawaban atas permasalahan dan tujuan penelitian, yaitu sebagai berikut:

1. Perkembangan bahasa Indonesia anak di Tk Darma Wanita kabupaten seluma, sudah dilakukan 


\begin{tabular}{|l|l|r|}
\hline & Al Fitrah & Pengaruh Guru PAUD dalam \\
Journal Of Early Childhood Islamic Education & Menstimulasi Perkembangan \\
ISSN $:$ 2599-2287 E-ISSN : 2622-335X & Kelompok B Usia 5-6 TAhun \\
Vol.3 No.1Juli 2019 & Wika Niati \\
\hline
\end{tabular}

namun perlu dilakukan peningkatan dalam perkembangan bahasa anak melalui berbicara,membaca, menulis dan menyimak, agar lebih menarik serta metode yang berbeda agar pemkembangan anak semakin meningkat dan anak dapat mengunakan bahasa Indonesia dalam berkomunikasi.

2. Peran guru dalam menstimulasi perkembangan anak berbagai metode atau media yang dilakukan di Tk Darma Wanita Kabupaten Seluma dengan memberikan contoh mengajar dan mestimulasi perkembangan bahasa agar anak terbiasa untuk berbahasa Indonesia serta menciptakan pembelajaran yang menarik salah satunya menggunakan media mengunakan bahasa Indonesia agar dapat meningkatkan kemampuan berbahasa pada anak.

\section{DAFTAR PUSTAKA}
Ahmad Tanzeh.2011. Metodologi Penelitian Praktis,. Yokyakarta: Teras
AksaraIsjoni.2011.Model Pembelajaran Anak Usia Dini. Bandung: Alfabeta.

Anita Yus. 2011. Model Pendidikan Anak Usia Dini. Jakarta: Kecana Prenanda Media Group.
Asep Dadang. 2007.Mencerdaskan IQ, EQ $D A N S Q$. Bandung: Globalindo

Djamarah Syaiful Bahri.2000. Pisikologi Belajar. Banjarmasin :IAIN Antasari Banjarmasin

Gunarti Winda, Lilis Suryani, Azizah Muis.2008. Metode Pengembangan Perilaku dan Kemampuan Dasar Anak Usia Dini. Jakarta: Universitas Terbuka

https://ghofar1.blogspot.com/2016/11/ayathadist-dalil-kewajibanmenghormati.html.23/11/2018

Ibrahim Bafadal,.2004. Dasar-Dasar Manajemen Dan Supervisi Taman Kanak-Kanak. Jakarta: Pt Bumi

Nelva Rolina,. 2012. Alat Permainan Edukatif Untuk Aud. Yogyakarta: Ombak

Oemar Hamalik, Perencanaan Pengajaran Berdasarkan Pendekatan Sistem. Jakarta: Pt Bumi Aksara

Sugiono. 2010. Metode Penelitian Bisnis (Pendekatan Kualitatuf, Kuantitatif dan $R \& D)$ Bandung : Alfabeta

Syaiful Bahri Djamarah.2010. Guru Dan Anak Didik Dalam Interaksi Edukatif (Suatu Pendekatan Teoritis Psikologi). Jakarta: PT Rineka Cipta.

Wiratna Sujarweni. 2009.Metodologi Penelitian, Yogyakarta:Pustaka Barupress

Yusuf Syamsu. 2011 Perkembangan Peserta Didik. Jakarta : PT Rajarafindo Persada 